\title{
ICT Use and Successful Learning: The Role of the Stock of Human Capital
}

\author{
Gregorio Gimenez ${ }^{1, *(D)}$ and Luis Vargas-Montoya ${ }^{1,2,3}$ (D) \\ 1 Faculty of Economics and Business Administration, Department of Applied Economics, \\ University of Zaragoza, 50005 Zaragoza, Spain; 772223@unizar.es \\ 2 Faculty of Economic Sciences, Economic Sciences Research Institute, University of Costa Rica, \\ 2060 San José, Costa Rica \\ 3 College of Economic Sciences of Costa Rica, 11503 Mercedes, Costa Rica \\ * Correspondence: gregim@unizar.es
}

Citation: Gimenez, G.; Vargas-

Montoya, L. ICT Use and Successful

Learning: The Role of the Stock of

Human Capital. Mathematics 2021, 9 ,

1648. https://doi.org/10.3390/

math9141648

Academic Editors: Sara

M. González-Betancor and

Carmen Pérez-Esparrells

Received: 8 June 2021

Accepted: 10 July 2021

Published: 13 July 2021

Publisher's Note: MDPI stays neutral with regard to jurisdictional claims in published maps and institutional affiliations.

\begin{abstract}
Previous empirical studies have found a weak nexus between the use of information and communication technologies (ICT) for learning and students' outcomes. However, this literature has not considered the role that the countries' stock of human capital can have in the successful use of ICT for learning. In this paper, we test empirically the existence of complementarities between human capital and technology adoption for learning. We carry out an empirical analysis with PISA data from a large-scale sample of 363,412 students enrolled in 13,215 schools in 48 countries. We estimate a hierarchical linear model (HLM) of three levels: students, schools, and countries. Our results strongly support the evidence of a positive externality of the stock of human capital on ICT use for learning. When we consider the moderator-effect of the stock of human capital, we find that the negative outcome of ICT use on students' outcomes in mathematics, reading and science turns positive (greater and more positive the higher the stocks of human capital are). The greater the stock of human capital an economy has, the more benefits it can get from investments in ICT for learning.
\end{abstract}

Keywords: ICT; technology; internet; computers; human capital; students; schools; teaching; academic achievement; educational outcomes; Programme for International Student Assessment (PISA)

\section{Introduction}

Information and communication technologies (ICT) have changed the world. Over the last decades, peoples' daily lives have undergone a profound transformation. It is difficult to conceive of life without computers, cell phones, social networks, and permanent access to information. Everything has become accessible and instantaneous.

Education has not been immune to this profound transformation. Computers, at first, and access to knowledge through the Internet, later, were identified as revolutionary educational tools. Computers and connectivity would make it possible, definitely, to democratize and universalize education. The teaching and learning applications available would allow quality to standardize. Following these premises, policy-makers in education have been investing, over the last decades, huge amounts of resources in making schools more technological and facilitating access to new technologies for students [1-4]. This interest has grown even further since the start of the COVID-19 pandemic, as many countries are accelerating the incorporation of ICT into education [5].

However, it is clear that digital transformation is coming at a cost. Digitization is meaning an increase in human beings' dependence on technological devices, and even its advantages in terms of productivity and efficiency are being questioned, as there is a discrepancy between measures of investment in information technology and measures of output [6].

This critical vision has become very evident in the educational field, where the effectiveness of new technologies in learning is increasingly questioned. The impact of ICT 
on educational achievements has become a controversial issue, and scientific evidence has not clearly found that the use of ICT in the classroom has a positive effect on learning [2,7-10]. One major motive is that the empirical studies carried out have paid little attention to the potential role of country characteristics in shaping the relationship between the use of ICT and educational achievement [8]. Among these characteristics, the stock of human capital, and specifically the interaction between it and the use of new technologies, emerges as a factor of singular relevance. The economic literature has highlighted the important complementarities that surge between human capital accumulation and technology adoption [11-16].

Following this line of thought, in the present article, we formulate the hypothesis that the outcome of the subject-related ICT use at school on learning varies when we consider differences in the countries' stock of human capital. We conjecture that the countries with greater stock of human capital can benefit more from the use of ICT in learning. In the next subsections, we explain what the literature has found about the relationship between ICT and learning success and why we think that this can be conditioned by the stock of human capital.

\subsection{ICT and Educational Outcomes}

There are both positive and negative arguments about the effectiveness of ICT for teaching and learning. On the one hand, ICT may ease individualized and flexible instruction, leading to improvements in students' outcomes by attending to their needs and potential [17]. The availability of vast ICT educational resources and information on the Internet also amplifies the scope of teaching and learning beyond the educational systems [18], which might enhance students' outcomes. ICT also provides audiovisual materials capable of stimulating motivation [19], creativity and innovation [20] in learning and teaching processes, leading to improvements in academic outcomes. On the other hand, when ICT is not well integrated into the curriculum, due to pedagogical barriers, they might hinder students from learning [21]. ICT may also discourage students' effort and logical thinking if educational systems do not fit technology to their ICT-instructional needs [22]. The ICT might further provide a lot of wrong or incomplete information, which can be used in education, diminishing students' learning [23]. The effectiveness of ICT on educational systems will depend on the net effect of these likely positive and negative contributions to academic outcomes.

Over the past two decades, a substantial amount of empirical research regarding the effectiveness of access to and use of ICT on academic outcomes using large-scale international surveys have been developed (for a literature review, see [9]). Studies based on large-scale international surveys (e.g., PISA, TIMSS, and PIRLS) allow comparisons between a broad range of settings and estimations of correlations among populations (e.g., schools, professors, and students) within countries and across them. Nevertheless, with these studies using cross-sectional data, it is difficult to infer causal relationships [24].

Since this paper is based on a large-scale international survey (Programme for International Student Assessment, PISA) and analyzes subject-related ICT use at school, in the following paragraphs, we present the main results of research conducted from international assessments and that analyzed the effectiveness of access to and use of ICT at school. Several studies have used international surveys (most commonly, PISA) to conduct analyses in single countries. Based on Spanish students' data from PISA 2012, Cabras and Tena Horrillo [25] estimated the effect of computer use at school on mathematics outcomes. They found that, with a high probability, computers use had a moderate positive effect on mathematics outcomes, which was particularly high among low-socioeconomicbackground students. Also based on PISA 2012 data from Spain, Alderete et al. [26] found a negative relationship between ICT use at school and reading, mathematics, and science outcomes. In another study in Spain, Gómez-Fernández and Mediavilla [23] used PISA 2015 to estimate the relationship between access to and use of ICT at school and reading, mathematics, and science outcomes. These authors found a positive relationship between 
the availability of computers and academic outcomes, whereas for the use of computers, it was negative. Using data from the 2009, 2012, and 2015 PISA results for Spanish students, Fernández-Gutiérrez et al. [2] estimated the effect of ICT use at school on the three PISA subjects' outcomes. Leveraging the availability of representative samples for Spanish regions and the autonomy and variability of ICT use at school across them, they found that increasing ICT use at school in an Autonomous Community did not have positive effects on reading and mathematics outcomes, while in science, it had positive effects. Based on PISA 2012 data for Turkish students, Erdogdu and Erdogdu [27] found a positive relationship between internet access and science outcomes, whereas for the frequency of internet browsing, it was negative for the three PISA subjects (reading, mathematics, and science). Using TIMMS 2011 data for Dutch students, De Witte and Rogge [28] estimated the effects of distinct ICT variables on mathematics outcomes. The authors found that these effects varied based on whether or not different student, teacher, school, and regional features were considered.

Other studies based on international assessments have conducted analyses for a set of countries. Using samples of 38 countries from TIMSS 2011 data, 43 countries from PIRLS 2011 data, and 39 countries from PISA 2012 data, Skryabin et al. [29] analyzed the relationship between ICT use and subjects' academic outcomes. They found a positive relationship between ICT use and reading, mathematics, and science outcomes for 4th grade students, while for 8th grade students, it was negative. Zhang and Liu [30] used a set of 25 countries from PISA 2000, 32 from PISA 2003, 40 from PISA 2006, 45 from PISA 2009, and 43 from PISA 2012 to estimate the relationship between various ICT use indicators and mathematics and science outcomes. These authors found a negative relationship between software and Internet use and both subjects' outcomes. Using data for 39 countries from PISA 2012, Petko et al. [31] estimated the relationship between ICT use and reading, mathematics, and science outcomes. They found a negative relationship between ICT use and academic outcomes in the vast majority of countries. Finally, based on a set of 30 countries from TIMSS 2011, Falck et al. [7] estimated the effects of distinct school computer uses on academic outcomes. The authors applied a within-student betweensubject identification, which leveraged the availability of information for each student on two different subjects (mathematics and science). They found positive effects from practicing skills and procedures on academic outcomes, while for processing and analyzing data, they were non-significant.

\subsection{The Role of Human Capital}

By human capital, we understand the knowledge and skills embodied in people, as it is seen as a form of capital incorporated into persons [32]. Nevertheless, for the purposes of this study, the key aspect of human capital has to do with its externalities. Human capital has been shown to be a key driver of economic growth and poverty alleviation, as it relates to economies' ability to maintain competitiveness, develop novel business ideas, and spur innovation and technology diffusion [33-35]. Traditionally, formal education is considered the main source of human capital. It has been widely used to measure its stock for three reasons: (a) it has a strong correlation with the acquisition paths of other resources (e.g., health and experience), (b) it constitutes the basis for the formation of competences and skills demanded in the labor market, and (c) data on enrollment rates is widely available from decades ago and is comparable internationally.

There are solid arguments to expect that the relationship between ICT and educational outcomes may differ depending on the countries' human capital level. Specifically, due to its strong positive externalities, we can point to three effects of the stock of human capital on learning through ICT:

1. The assimilation and effective use of technology. We consider the stock of human capital as a catalyst of new technologies: the process of adoption of new technologies is strongly influenced by the human capital stock, by reducing new technologies' learning costs and accelerating their adoption [15,36-38]. 
2. The creation and improvement of a pedagogical and institutional environment more conducive to learning. Human capital diminishes criminal activity [39], increases civic participation [40], improves adaptive capacity to environmental change [41], and spurs entrepreneurship and business outcomes.

3. The attraction of better teachers. Highly educated areas experience faster population and employment growth as individuals flock to be near the highly educated [42]. Moreover, it is mostly educated individuals who are moving to high human capital areas, seeking a better quality of life $[43,44]$. These effects have specifically been found in the case of teachers: their well-being and productivity can increase by interacting with and learning from high-skilled teachers $[45,46]$.

The goal of the present study is to provide a theoretical and empirical underpinning towards a better understanding of the role of the stock of human capital in the successful use of ICT for education in the learning process. To do so, we estimate an education production function that empirically establishes the relationship between the student's outcomes, in the form of tests' scores in mathematics, reading, and science (output) and a wide set of explaining variables (inputs), among them, the subject-related ICT use at schools. In the function, we include the stock of human capital and its interaction with the subject-related ICT use, to assess whether, and how, human capital has a moderator-effect on the relationship between ICT use and students' outcomes. This approach constitutes, as far as we know, a novelty in the literature. We find that, although subject-related ICT use at schools has a negative relationship with students' outcomes, when we consider the moderator-effect of the stock of human capital in the estimations, this relationship turns positive. The relationship between subject-related ICT use at schools and students' outcomes is greater (more positive) the higher the level of the stock of human capital is. The higher the stock of human capital an economy has, the more benefits can be had from investments in ICT for learning. Similarly, the higher the subject-related ICT use, the greater (more positive) the result of the stock of human capital on students' outcomes.

The remainder of the paper is organized as follows. In the next section, we explain the data, variables, and methodology used in the paper. Section 3 describes the results. Section 4 discusses the findings and concludes the paper.

\section{Materials and Methods}

The current study developed an empirical analysis aiming to answer the following question: Whether, and how, the countries' stock of human capital has a moderator-effect on the relationship between subject-related ICT use at schools and students' outcomes.

\subsection{Data}

The analysis used, as the main source, data coming from the 2018 edition of the PISA questionnaire, released in 2020. This questionnaire has been carried out by the Organization for Economic Co-operation and Development (OECD) every three years since 2000. Its objective is to evaluate educational systems by measuring 15-year-olds' ability to use their reading, mathematics, and science knowledge and skills to meet real-life challenges [47]. In addition, the questionnaire contains information about the students' background, their schools, and learning environment. Specifically, there is a module called ICT familiarity questionnaire devoted to asking about the students' ICT access and use at school and home.

The key variable of the ICT module that we incorporated into our study was the PISA index subject-related ICT use during lessons (PISA code ICTCLASS). The use of this variable is a significant novelty compared to previous cross-country studies, as it allows us to work with a measurement of subject-related ICT use at school. Previous studies were mostly based on access to and general use of ICT, without distinguishing between academic and leisure purposes. Theoretical arguments in favor of a positive effect of academic use of ICT on educational attainment suggest that they can improve student outcomes by: (a) increasing access to information and to a wider range of resources for learning; (b) improving teaching materials and making lessons more complete, engaging, 
and interactive; (c) promoting individualized instruction and the better monitoring of student progress; (d) increasing the flexibility and autonomy of students; and (e) reducing educational costs $[2-4,26,28,48]$. PISA constructed this index measuring the use of ICT for academic activities from five questions that asked about the time students spent using digital devices during classroom lessons in a typical school week in the following subjects: test language lessons, mathematics, science, foreign language, and social sciences. Each question considered four possible responses: "No time", "1-30 min a week", "31-60 min a week", and "More than $60 \mathrm{~min}$ a week". Applying the item response theory scaling to this information, PISA computed the standardized single index ICTCLASS.

Since our paper analyzed the relationship between academic outcomes and subjectrelated ICT use at schools, mediated by the stock of human capital from an international perspective, we merged the PISA dataset with two measures of the stock of human capital widely used in the literature: the stock of human capital indicator coming from Barro and Lee (BL) dataset [49] and the one coming from the Penn World Table (PWT) [50].

For decades, schooling has been used as the main proxy for human capital, which has mostly been measured in terms of the highest educational attainment distribution of the population or the aggregated mean years of schooling [51]. Following the mainstream, we incorporated in our study a measure of the average years of schooling constructed by BL, based on the percentage of the population, aged 25-years-old and above, who have completed primary, secondary, and tertiary education.

Over recent years, some researchers have made valuable efforts to build more elaborated and accurate indicators of the stock of human capital [16]. Among these new attempts, the index of human capital included in the PWT has received great attention from scholars and policy makers. This index is constructed by making a Mincerian transformation of the average years of schooling calculated by BL. It estimates the stock of human capital $(h c)$ of a country $i$ at time $t$ as a function of the average years of schooling (s):

$$
h c_{i t}=e^{\phi\left(s_{i t}\right)},
$$

where $\phi(s)$ are the Mincerian rates of return to education defined by Psacharopoulos (1994) [52].

Table 1 shows countries' average values for the ICTCLASS index and for the BL and PWT stock of human capital indicators. The average ICTCLASS index in our sample was of -0.07 with a standard deviation of 0.34 . It ranged from the one of Japan $(-0.59)$ to the one of Denmark (1.35). The BL indicator average was of 10.54 with a standard deviation of 1.95. It ranged from the one of Morocco (4.24) to the one of the United States (13.42). The average value of the PWT indicator was of 3.23, and its standard deviation was 0.41 . It ranged from the one of Morocco (1.89) to the one of Singapore (3.97).

The 2018 edition of the PISA questionnaire surveyed 612,004 students from to 21,903 schools distributed in 79 countries and economies. But only the students of 49 countries answered the PISA ICT familiarity questionnaire. Considering that Georgia had to be excluded from the sample of countries that had completed the ICT familiarity questionnaire, because it had no available information about its stock of human capital, our final sample was reduced to 363,412 students, enrolled in 13,215 schools in 48 countries (12 middle-income and 36 high-income economies). Table 2 shows the classification and descriptive statistics of the variables employed to analyze our final sample. 
Table 1. List of countries in the sample and their average values in the PISA index subject-related ICT use during lessons (ICTCLASS), years of schooling (BL), and years of schooling (PWT).

\begin{tabular}{|c|c|c|c|c|}
\hline Country Code & Country Name & ICTCLASS & BL & PWT \\
\hline ALB & Albania & -0.23 & 9.85 & 2.95 \\
\hline AUS & Australia & 0.61 & 11.77 & 3.52 \\
\hline BEL & Belgium & -0.20 & 10.78 & 3.14 \\
\hline BRA & Brazil & -0.48 & 7.66 & 2.95 \\
\hline BRN & Brunei & -0.25 & 8.77 & 2.77 \\
\hline BGR & Bulgaria & -0.02 & 11.45 & 3.16 \\
\hline $\mathrm{CHL}$ & Chile & -0.09 & 9.71 & 3.11 \\
\hline CRI & Costa Rica & -0.28 & 7.84 & 2.66 \\
\hline HRV & Croatia & -0.31 & 11.42 & 3.52 \\
\hline CZE & Czech Republic & -0.28 & 13.16 & 3.67 \\
\hline DNK & Denmark & 1.35 & 11.53 & 3.56 \\
\hline DOM & $\begin{array}{c}\text { Dominican } \\
\text { Republic }\end{array}$ & -0.35 & 7.46 & 2.72 \\
\hline EST & Estonia & 0.00 & 12.48 & 3.62 \\
\hline FIN & Finland & 0.08 & 10.21 & 3.47 \\
\hline FRA & France & -0.18 & 10.64 & 3.19 \\
\hline GBR & Great Britain & -0.11 & 12.32 & 3.76 \\
\hline GRC & Greece & -0.39 & 10.26 & 3.09 \\
\hline HKG & Hong Kong & -0.37 & 11.02 & 3.24 \\
\hline HUN & Hungary & -0.30 & 12.14 & 3.38 \\
\hline ISL & Iceland & 0.41 & 10.59 & 3.23 \\
\hline IRL & Ireland & -0.36 & 12.20 & 3.15 \\
\hline ISR & Israel & -0.06 & 12.76 & 3.81 \\
\hline ITA & Italy & -0.06 & 9.54 & 3.12 \\
\hline JPN & Japan & -0.59 & 11.52 & 3.57 \\
\hline KAZ & Kazakhstan & 0.32 & 11.42 & 3.14 \\
\hline KOR & Korea & 0.07 & 11.89 & 3.69 \\
\hline LVA & Latvia & -0.12 & 10.48 & 3.13 \\
\hline LTU & Lithuania & 0.03 & 11.05 & 3.26 \\
\hline LUX & Luxemburg & -0.31 & 11.22 & 3.51 \\
\hline MAC & Macao & -0.05 & 8.09 & 2.86 \\
\hline MLT & Malta & -0.07 & 10.33 & 3.13 \\
\hline MEX & Mexico & -0.29 & 8.33 & 2.74 \\
\hline MAR & Morocco & -0.27 & 4.24 & 1.89 \\
\hline NLD & Netherlands & -0.05 & 11.60 & 3.37 \\
\hline PAN & Panama & -0.40 & 9.15 & 2.86 \\
\hline POL & Poland & -0.20 & 11.42 & 3.40 \\
\hline RUS & Russia & 0.06 & 11.73 & 3.40 \\
\hline SRB & Serbia & -0.22 & 10.97 & 3.39 \\
\hline SGP & Singapore & -0.33 & 10.63 & 3.97 \\
\hline SVK & Slovakia & 0.00 & 13.07 & 3.79 \\
\hline SVN & Slovenia & -0.34 & 12.13 & 3.53 \\
\hline ESP & Spain & -0.05 & 10.30 & 2.94 \\
\hline SWE & Sweden & 0.77 & 11.89 & 3.42 \\
\hline $\mathrm{CHE}$ & Switzerland & -0.24 & 13.42 & 3.69 \\
\hline THA & Thailand & 0.13 & 7.30 & 2.74 \\
\hline TUR & Turkey & 0.22 & 6.56 & 2.44 \\
\hline USA & United States & 0.38 & 13.42 & 3.74 \\
\hline URY & Uruguay & -0.11 & 8.11 & 2.73 \\
\hline
\end{tabular}


Table 2. Variable classification and descriptive statistics.

\begin{tabular}{|c|c|c|c|c|}
\hline Type of Variable & Variable & Mean & SD & Missing (\%) \\
\hline \multirow{3}{*}{$\begin{array}{l}\text { Dependent } \\
\text { variables }\end{array}$} & Reading score & 465 & 104.0 & 9.9 \\
\hline & Mathematics score & 472 & 95.1 & 0.0 \\
\hline & Science score & 470 & 95.5 & 0.0 \\
\hline \multirow{9}{*}{$\begin{array}{l}\text { Student-level } \\
\text { predictors }\end{array}$} & Subject-related ICT use during lessons (CI) & -0.05 & 1.0 & 15.9 \\
\hline & Age & 15.8 & 0.3 & 0.0 \\
\hline & Economic, social, and cultural status (CI) & -0.2 & 1.1 & 2.4 \\
\hline & Gender & & & 0.0 \\
\hline & Female & 49.9 & & \multirow{5}{*}{2.8} \\
\hline & Male & 50.1 & & \\
\hline & Country of birth & & & \\
\hline & Country of the test & 93.3 & & \\
\hline & Other country & 6.7 & & \\
\hline \multirow{17}{*}{$\begin{array}{l}\text { School-level } \\
\text { predictors }\end{array}$} & Proportion of all teachers fully certified (CI) & 0.84 & 0.3 & 16.9 \\
\hline & Teacher behavior hindering learning (CI) & 0.17 & 1.1 & 4.5 \\
\hline & Perceived teacher's interest (CI) & 0.08 & 1.0 & 4.9 \\
\hline & Shortage of educational material (CI) & 0.06 & 1.1 & 4.8 \\
\hline & Shortage of educational staff $(\mathrm{CI})$ & -0.02 & 1.0 & 4.9 \\
\hline & Adaptation of instruction (CI) & 0.02 & 1.0 & 5.6 \\
\hline & $\begin{array}{l}\text { Disciplinary climate in test language lessons } \\
(\mathrm{CI})\end{array}$ & 0.07 & 1.1 & 3.4 \\
\hline & Which of the following definitions best & & & \multirow{10}{*}{12.7} \\
\hline & $\begin{array}{l}\text { describes } \\
\text { the community in which your school is located? }\end{array}$ & & & \\
\hline & A large city (with over $1,000,000$ people) & 14.3 & & \\
\hline & A city $(100,000$ to about $1,000,000$ people $)$ & 27.0 & & \\
\hline & A town $(15,000$ to about 100,000 people $)$ & 30.3 & & \\
\hline & A small town (3000 to about 15,000 people) & 19.4 & & \\
\hline & $\begin{array}{c}\text { A village, hamlet or rural area (fewer than } 3000 \\
\text { people) }\end{array}$ & 9.0 & & \\
\hline & Is your school a public or a private school? & & & \\
\hline & Private school & 20.6 & & \\
\hline & Public school & 79.41 & & \\
\hline \multirow{3}{*}{$\begin{array}{l}\text { Country-level } \\
\text { predictors }\end{array}$} & Years of schooling (BL) & 10.50 & 1.8 & 0.0 \\
\hline & Years of schooling (PWT) & 3.21 & 0.4 & 0.0 \\
\hline & $\begin{array}{l}\text { Gross domestic product per capita (GDP } \\
\text { per capita) }\end{array}$ & 40,700 & 21,700 & 0.0 \\
\hline
\end{tabular}

Notes: CI indicates a composite indicator built by the PISA project work group. In this case, Cronbach's alpha was used to check the internal consistency of each scale. In categorical variables, values reflect the percentage of cases in each category. The variable Gross domestic product per capita (GDP per capita) is in current international \$ corrected by purchasing power parity and was obtained from: https://data.worldbank.org/indicator/NY.GDP.PCAP.PP.CD (accessed on 9 May 2021). The exclusion of all the missing values in the final sample would have generated a loss of 142,569 observations ( $39 \%$ of our final sample). This would have led to the statistical inference to be biased [53-55]. We used data imputation to carry out the analyses, avoiding the reduction of the sample size and mitigating the estimation bias [56]. The missing values were imputed with the $\mathrm{R}$ package Multivariate Imputation by Chained Equations, which computes incomplete multivariate data by fully conditional specification (FCS) Since PISA 2018 excluded Spain's results from the reading assessment for technical issues, the reading score had 35,943 missing values that were not imputed. Source: made by the authors.

\subsection{Model}

We established a statistical relationship between the students' outcomes in each PISA subject (mathematics, reading, and science, which are the dependent variables) and the learning factors (predictors). To increase the accuracy of students' scores measurement, PISA generated ten plausible values, for each student, in the three subjects. We used the same methodology as previous studies that defined the dependent variable as the student's mean scores of the plausible values [57,58].

The dataset that we used presented a nested structure: students were grouped in schools, and schools in countries. This type of clustered data violates the assumption of independence of the observations. This is, observations within each group were probably correlated, because the individuals belonging to the same groups shared common characteristics. In the case of the schools, students enrolled in the same schools might have similar social background; they might influence each other, or their school might deliver education in a particular manner that make its students' outcomes differ from the outcomes of those 
enrolled in other schools. In the case of countries, students of the same country might share the same culture, values, and idiosyncratic educational issues.

Hierarchical linear models (HLM) are suitable to deal with data that presents this nested structure. They consider this clustered structure by identifying random effects. In our case, we included school- and country-specific random intercepts, which allowed schools and countries to vary from the average PISA scores when the covariates were zero. This let us to estimate robust standard errors. By doing so, we expected the correlation between the residuals of the predicted students' outcomes, for every school or country in the sample, to be different from zero.

Specifically, the three-level model that we used can be expressed as:

$$
\begin{gathered}
\boldsymbol{Y}_{i j k}=\beta_{0}+\beta_{1} \boldsymbol{X}_{1 i j k}+\beta_{2} \boldsymbol{Z}_{j k}+\beta_{3} \text { ICTCLASS }_{1 i j k}+\beta_{4} \text { GDP }_{k}+\beta_{5} H_{k}+\beta_{6} \text { ICTCLASS }_{1 i j k} \cdot H_{k}+\varepsilon_{i j k} \\
\beta_{0}=\gamma_{00}+u_{0 j k}+v_{0 k}
\end{gathered}
$$

In Equation (2), $Y_{i j k}$ was the expected PISA score for student $i$ enrolled in school $j$ in a country $k ; \boldsymbol{X}_{i j k}$ and $\boldsymbol{Z}_{j k}$ were, respectively, vectors of predictors at the student and school levels; ICTCLASS 1 ijk measured the time devoted to subject-related ICT use for student $i$ in school $j$ and country $k ; G D P_{\mathrm{k}}$ and $H_{\mathrm{k}}$ were, respectively, the GDP per capita and the stock of human capital at the country- level; ICTCLASS $1 i j k \cdot H_{k}$ was the term that reflected the interaction between the stock of human capital and subject-related ICT use at schools; finally, $\varepsilon_{i j k}$ was the unexplained component of the model.

$\boldsymbol{X}_{i j k}$ and $\boldsymbol{Z}_{j k}$ included a set of students', teachers' and schools' characteristics that are considered standard in the literature to predict students' outcomes. Specifically, gender (PISA code ST004D01T), age (PISA code AGE), country of birth (PISA code ST019AQ01T), a composite index of economic, social and cultural status of the household (PISA code ESCS), an index showing the proportion of all teachers fully certified (PISA code PROATCE), an index of teacher behavior hindering learning (PISA code TEACHBEHA), an index of perceived teacher's interest (PISA code TEACHINT), an index of shortage of educational material (PISA code EDUSHORT), an index of shortage of educational staff (PISA code STAFFSHORT), an index of adaptation of instruction to improve learning (PISA code ADAPTIVITY), an index of disciplinary climate in test language lessons (PISA code DISCLIMA), the size of the community in which the school was located (PISA code SC001Q01TA), and if the school was public or private (PISA code SC013Q01TA).

For an in-depth justification of the inclusion of these predictors that act as control variables and the role that they play in the learning process, see Bradley and Green [59], Hanushek and Welch [60], and Hanushek et al. [9,24,61]. We expected to find gender differences, as girls used to score higher in reading but lower in mathematics and science. Students who were older, did not have immigrant background, lived in households with higher economic, social and cultural status, lived in richer countries, and attended private schools or schools that were situated in larger communities were expected to have better outcomes. The index showing the proportion of all teachers fully certified, the index of perceived teacher's interest, the index of adaptation of instruction, and the index of disciplinary climate in test language lessons were expected to correlate positively with students' outcomes. Conversely, the index of teacher behavior hindering learning, the index of shortage of educational material, and the index of shortage of educational staff were expected to correlate negatively.

Equation (3) was estimated simultaneously with Equation (2) and allowed us to model the school- and country-specific intercepts. The associated complex error structure $u_{0 j k}$ and $v_{0 k}$ were the respective deviation of the schools' and the countries' means from the overall mean $\gamma_{00}$. They were assumed to be normally distributed, with mean zero, and uncorrelated with $\varepsilon_{i j k}$.

Our hypothesis was that students who lived in environments with higher stocks of human capital could benefit directly and indirectly (via the use of ICT) by obtaining better outcomes. To obtain clearer and more intuitive evidence of the interaction between subjectrelated ICT use during lessons and human capital, we conducted estimations centered 
at the country mean of the stock of human capital indicators [62]. This facilitated the interpretation of the results.

\section{Results}

Tables 3 and 4 show the results of the estimations of Equations (2) and (3) for mathematics, reading, and science; and both the BL (Table 3) and PWT (Table 4) indicators of the stock of human capital. The tables include two parts: one general, common to all contexts (which is the so-called fixed-effects), and another that represents the context of each group (random-effects), which in our case are schools and countries. The latter, at the bottom of the table, shows the standard deviations from the overall mean, with origin in the school-and-country-level variance unaccounted for in the model and the residual variance component.

Table 3. HLM estimations predicting students' outcomes and considering years of schooling (BL) as an indicator of the countries' stock of human capital.

\begin{tabular}{|c|c|c|c|c|c|c|c|}
\hline \multirow[b]{2}{*}{$\begin{array}{l}\text { Type of } \\
\text { Variable }\end{array}$} & \multirow[b]{2}{*}{ Variable } & \multicolumn{2}{|c|}{ Reading } & \multicolumn{2}{|c|}{ Mathematics } & \multicolumn{2}{|c|}{ Science } \\
\hline & & Estimate & SE & Estimate & SE & Estimate & SE \\
\hline \multirow{22}{*}{$\begin{array}{l}\text { Fixed } \\
\text { effects }\end{array}$} & $\begin{array}{c}\text { Intercept } \\
\text { Gender-Female (base) }\end{array}$ & $303.10 * * *$ & 11.48 & $271.80^{* * *}$ & 11.05 & $298.20 * * *$ & 10.95 \\
\hline & Male & $-21.00 * * *$ & 0.27 & $10.02 * * *$ & 0.22 & $2.93 * * *$ & 0.24 \\
\hline & Age & $9.58^{* * *}$ & 0.46 & $10.46^{* * *}$ & 0.38 & $9.14^{* * *}$ & 0.40 \\
\hline & $\begin{array}{c}\text { Country of birth-Country of the } \\
\text { test (base) }\end{array}$ & & & & & & \\
\hline & Other country & $-13.55^{* * *}$ & 0.56 & $-10.19^{* * *}$ & 0.45 & $-12.21^{* * *}$ & 0.48 \\
\hline & Economic, social, and cultural status & $13.75^{* * *}$ & 0.15 & $14.85^{* * *}$ & 0.13 & $14.60^{* * *}$ & 0.13 \\
\hline & $\begin{array}{c}\text { Proportion of all teachers fully } \\
\text { certified }\end{array}$ & $2.58^{* *}$ & 1.19 & 0.93 & 1.01 & $1.75 *$ & 1.04 \\
\hline & Teacher behavior hindering learning & -0.11 & 0.34 & -0.23 & 0.29 & -0.17 & 0.30 \\
\hline & Perceived teacher's interest & $2.73^{* * *}$ & 0.15 & $1.81 * * *$ & 0.13 & $2.27^{* * *}$ & 0.13 \\
\hline & Shortage of educational material & $-3.38 * * *$ & 0.43 & $-3.04 * * *$ & 0.37 & $-2.98^{* * *}$ & 0.37 \\
\hline & Shortage of educational staff & $-2.27 * * *$ & 0.42 & $-1.90 * * *$ & 0.36 & $-2.05^{* * *}$ & 0.37 \\
\hline & Adaptation of instruction & $4.35^{* * *}$ & 0.15 & $3.08 * * *$ & 0.12 & $3.48^{* * *}$ & 0.13 \\
\hline & $\begin{array}{c}\text { Disciplinary climate in test } \\
\text { language lessons } \\
\text { School location-A large city (with } \\
\text { over } 1,000,000 \text { people) (base) }\end{array}$ & $6.43^{* * *}$ & 0.14 & $5.85^{* * *}$ & 0.11 & $5.77^{* * *}$ & 0.12 \\
\hline & $\begin{array}{l}\text { A city }(100,000 \text { to about } \\
1,000,000 \text { people })\end{array}$ & $-3.38^{* * *}$ & 1.24 & $-2.57^{* *}$ & 1.07 & $-2.58^{* *}$ & 1.10 \\
\hline & $\begin{array}{c}\text { A town }(15,000 \text { to about } \\
100,000 \text { people })\end{array}$ & $-8.45^{* * *}$ & 1.23 & $-6.95 * * *$ & 1.06 & $-6.58^{* * *}$ & 1.09 \\
\hline & $\begin{array}{l}\text { A small town (3000 to about } \\
15,000 \text { people) }\end{array}$ & $-13.46^{* * *}$ & 1.35 & $-10.02^{* * *}$ & 1.16 & $-9.97^{* * *}$ & 1.20 \\
\hline & $\begin{array}{c}\text { A village, hamlet or rural area (fewer } \\
\text { than } 3000 \text { people) } \\
\text { Public or a private school?-Private } \\
\text { school (base) }\end{array}$ & $-21.04^{* * *}$ & 1.48 & $-14.69^{* * *}$ & 1.28 & $-15.09^{* * *}$ & 1.32 \\
\hline & Public school & $-4.25^{* * *}$ & 0.78 & $-4.03^{* * *}$ & 0.66 & $-3.98^{* * *}$ & 0.69 \\
\hline & $\begin{array}{l}\text { Gross domestic product per capita } \\
\text { (GDP per capita) }\end{array}$ & $0.75^{* * *}$ & 0.18 & $0.92^{* * *}$ & 0.19 & $0.80^{* * *}$ & 0.18 \\
\hline & $\begin{array}{c}\text { Subject-related ICT use during } \\
\text { lessons (ICTCLASS) }\end{array}$ & $-3.62^{* * *}$ & 0.14 & $-1.82^{* * *}$ & 0.12 & $-2.28^{* * *}$ & 0.12 \\
\hline & Years of schooling (BL) & $8.87^{* * *}$ & 2.29 & $9.53 * * *$ & 2.40 & $7.62 * * *$ & 2.31 \\
\hline & $\begin{array}{c}\text { Interaction between ICTCLASS and } \\
\text { years of schooling (BL) }\end{array}$ & $1.28^{* * *}$ & 0.07 & $1.02^{* * *}$ & 0.06 & $1.15^{* * *}$ & 0.06 \\
\hline \multirow{3}{*}{$\begin{array}{l}\text { Random } \\
\text { effects }\end{array}$} & Level 2: Intercept & 2275.00 & 47.70 & 1903.90 & 43.63 & 1901.70 & 43.61 \\
\hline & Level 3: Intercept & 848.20 & 29.12 & 943.50 & 30.72 & 870.40 & 29.50 \\
\hline & Level 1: Residual & 5204.60 & 72.14 & 3983.60 & 63.12 & 4430.30 & 66.56 \\
\hline \multirow{3}{*}{ Sample size } & Total sample (students) & \multicolumn{2}{|c|}{327,469} & \multicolumn{2}{|c|}{363,412} & \multicolumn{2}{|c|}{363,412} \\
\hline & Level 2 groups (schools) & \multicolumn{2}{|c|}{12,126} & \multicolumn{2}{|c|}{13,215} & \multicolumn{2}{|c|}{13,215} \\
\hline & Level 3 groups (countries) & \multicolumn{2}{|c|}{47} & \multicolumn{2}{|c|}{48} & \multicolumn{2}{|c|}{48} \\
\hline
\end{tabular}


Table 4. HLM estimations predicting students' outcomes and considering years of schooling (PWT) as indicator of the countries' stock of human capital.

\begin{tabular}{|c|c|c|c|c|c|c|c|}
\hline \multirow[b]{2}{*}{$\begin{array}{l}\text { Type of } \\
\text { Variable }\end{array}$} & \multirow[b]{2}{*}{ Variable } & \multicolumn{2}{|c|}{ Reading } & \multicolumn{2}{|c|}{ Mathematics } & \multicolumn{2}{|c|}{ Science } \\
\hline & & Estimate & SE & Estimate & SE & Estimate & SE \\
\hline \multirow{23}{*}{$\begin{array}{l}\text { Fixed } \\
\text { effects }\end{array}$} & Intercept & $305.80^{* * *}$ & 11.32 & $274.00^{* * *}$ & 11.09 & $300.80^{* * *}$ & 10.85 \\
\hline & Gender-Female (base) & & & & & & \\
\hline & Male & $-21.00 * * *$ & 0.27 & $10.00^{* * *}$ & 0.22 & $2.92 * * *$ & 0.24 \\
\hline & Age & $9.57^{* * *}$ & 0.46 & $10.45^{* * *}$ & 0.38 & $9.14^{* * *}$ & 0.40 \\
\hline & $\begin{array}{c}\text { Country of birth-Country of } \\
\text { the test (base) }\end{array}$ & & & & & & \\
\hline & Other country & $-13.56^{* * *}$ & 0.56 & $-10.20^{* * *}$ & 0.45 & $-12.23^{* * *}$ & 0.48 \\
\hline & $\begin{array}{c}\text { Economic, social, and cultural } \\
\text { status }\end{array}$ & $13.76^{* * *}$ & 0.15 & $14.86^{* * *}$ & 0.13 & $14.61^{* * *}$ & 0.13 \\
\hline & $\begin{array}{c}\text { Proportion of all teachers fully } \\
\text { certified }\end{array}$ & $2.62 * *$ & 1.19 & 0.95 & 1.01 & $1.78 *$ & 1.04 \\
\hline & $\begin{array}{c}\text { Teacher behavior hindering } \\
\text { learning }\end{array}$ & -0.11 & 0.34 & -0.23 & 0.29 & -0.17 & 0.30 \\
\hline & Perceived teacher's interest & $2.73^{* * *}$ & 0.15 & $1.82^{* * *}$ & 0.13 & $2.27 * * *$ & 0.13 \\
\hline & $\begin{array}{l}\text { Shortage of educational } \\
\text { material }\end{array}$ & $-3.39^{* * *}$ & 0.43 & $-3.04^{* * *}$ & 0.37 & $-2.98^{* * *}$ & 0.37 \\
\hline & Shortage of educational staff & $-2.26^{* * *}$ & 0.42 & $-1.90^{* * *}$ & 0.36 & $-2.04^{* * *}$ & 0.37 \\
\hline & Adaptation of instruction & $4.34^{* * *}$ & 0.15 & $3.08^{* * *}$ & 0.12 & $3.48^{* * *}$ & 0.13 \\
\hline & $\begin{array}{c}\text { Disciplinary climate in test } \\
\text { language lessons } \\
\text { School location-A large city } \\
\text { (with over } 1,000,000 \text { people) } \\
\text { (base) }\end{array}$ & $6.43^{* * *}$ & 0.14 & $5.85^{* * *}$ & 0.11 & $5.77^{* * *}$ & 0.12 \\
\hline & $\begin{array}{l}\text { A city }(100,000 \text { to about } \\
1,000,000 \text { people })\end{array}$ & $-3.34^{* * *}$ & 1.24 & $-2.54^{* * *}$ & 1.07 & $-2.55^{* *}$ & 1.10 \\
\hline & $\begin{array}{c}\text { A town }(15,000 \text { to about } \\
100,000 \text { people })\end{array}$ & $-8.40^{* * *}$ & 1.23 & $-6.92^{* * *}$ & 1.06 & $-6.54^{* * *}$ & 1.09 \\
\hline & $\begin{array}{c}\text { A small town (3000 to about } \\
15,000 \text { people) }\end{array}$ & $-13.41^{* * *}$ & 1.35 & $-9.99 * * *$ & 1.16 & $-9.94^{* * *}$ & 1.20 \\
\hline & $\begin{array}{c}\text { A village, hamlet or rural area } \\
\text { (fewer than } 3000 \text { people) } \\
\text { Public or a private } \\
\text { school?-Private school (base) }\end{array}$ & $-20.98^{* * *}$ & 1.48 & $-14.65^{* * *}$ & 1.28 & $-15.05^{* * *}$ & 1.32 \\
\hline & Public school & $-4.28^{* * *}$ & 0.77 & $-4.05^{* * *}$ & 0.66 & $-4.01^{* * *}$ & 0.69 \\
\hline & $\begin{array}{l}\text { Gross domestic product per } \\
\text { capita (GDP per capita) }\end{array}$ & $0.66^{* * *}$ & 0.18 & $0.85^{* * *}$ & 0.19 & $0.72^{* * *}$ & 0.18 \\
\hline & $\begin{array}{l}\text { Subject-related ICT use during } \\
\text { lessons (ICTCLASS) }\end{array}$ & $-3.77^{* * *}$ & 0.14 & $-1.82^{* * *}$ & 0.12 & $-2.27^{* * *}$ & 0.12 \\
\hline & Years of schooling (PWT) & $48.40^{* * *}$ & 10.88 & $47.72^{* * *}$ & 11.70 & $41.73^{* * *}$ & 11.02 \\
\hline & $\begin{array}{l}\text { Interaction between ICTCLASS } \\
\text { and years of schooling (PWT) }\end{array}$ & $6.94^{* * *}$ & 0.34 & $4.44^{* * *}$ & 0.29 & $5.54 * * *$ & 0.31 \\
\hline \multirow{3}{*}{$\begin{array}{l}\text { Random } \\
\text { effects }\end{array}$} & Level 2: Intercept & 2271.40 & 47.66 & 1899.70 & 43.59 & 1902.80 & 43.62 \\
\hline & Level 3: Intercept & 786.70 & 28.05 & 820.60 & 28.65 & 926.50 & 30.44 \\
\hline & Level 1: Residual & 5203.50 & 72.13 & 4430.30 & 66.56 & 3984.10 & 63.12 \\
\hline \multirow{3}{*}{$\begin{array}{l}\text { Sample } \\
\text { size }\end{array}$} & Total sample (students) & \multicolumn{2}{|c|}{327,469} & \multicolumn{2}{|c|}{363,412} & \multicolumn{2}{|c|}{363,412} \\
\hline & Level 2 groups (schools) & \multicolumn{2}{|c|}{12,126} & \multicolumn{2}{|c|}{13,215} & \multicolumn{2}{|c|}{13,215} \\
\hline & Level 3 groups (countries) & \multicolumn{2}{|c|}{47} & \multicolumn{2}{|c|}{48} & \multicolumn{2}{|c|}{48} \\
\hline
\end{tabular}

Note: ${ }^{* * *} p<0.01,{ }^{* *} p<0.05,{ }^{*} p<0.1$. Source: made by the authors.

The results that we found were robust regardless of the stock of human capital indicator considered and subject analyzed. First, male students scored higher in mathematics and science but lower in reading $(p<0.01)$. Second, age was positively correlated with students' outcomes $(p<0.01)$. Third, students who had an immigrant background had 
lower outcomes $(p<0.01)$. Fourth, economic, social, and cultural status was positively related with outcomes $(p<0.01)$. Fifth, the proportion of all teachers fully certified was correlated positively for reading $(p<0.05)$ and science $(p<0.10)$, while for mathematics the coefficient was not significant $(p>0.1)$. Sixth, the index of teacher behavior hindering learning correlated negatively and with a not-significant result $(p>0.1)$. Seventh, the index of perceived teacher's interest correlated positively $(p<0.01)$. Eight, the index of shortage of educational material correlated negatively $(p<0.01)$. Ninth, the index of shortage of educational staff correlated negatively $(p<0.01)$. Tenth, the index of adaptation of instruction correlated positively $(p<0.01)$. Eleventh, the index of disciplinary climate in test language lessons correlated positively $(p<0.01)$. Twelfth, students that attended schools situated in smaller communities scored lower $(p<0.01$ and $p<0.05)$. Thirteenth, students attending public schools scored lower $(p<0.01)$. Fourteenth, GDP per capita correlated positively with students' outcomes $(p<0.01)$.

As regards our central variables of study, the estimated coefficients and standard errors showed that the time devoted to subject-related ICT use in schools was associated negatively with students' outcomes $(p<0.01)$. The stock of human capital, both measured by the BL and PWT indicators, was correlated positively $(p<0.01)$. Additionally, finally, the interaction between the time devoted to subject-related ICT use in schools and the stock of human capital was correlated positively $(p<0.01)$. A positive value for the coefficient of the interaction term between the stock of human capital and subject-related ICT use implies that the higher the stock of human capital, the greater (more positive) the relationship between the subject-related ICT use and students' outcomes. Similarly, the higher the subject-related ICT use, the greater (more positive) the relationship between the stock of human capital and students' outcomes. For any given level of the stock of human capital for the countries included in our sample, the relationship between subject-related ICT use and students' outcomes turned positive once moderated by its stock of human capital.

All in all, the estimations showed that there was a negative correlation between subject-related ICT use in schools and students' outcomes. However, when we considered the moderator-effect of the stock of human capital, we found that the effect of ICT use on students' outcomes was greater the higher the stock of human capital was. The higher the stock of human capital an economy had, the more benefits could be had from investments in ICT for learning. These results were robust for both definitions of human capital: average years of schooling (BL) and average years of schooling weighted by the Mincerian rates of return to education (PWT).

\section{Discussion}

Previous empirical studies have found a weak nexus between the use of ICT for learning and students' outcomes. However, this literature has not taken into account the role that the countries' stock of human capital can have in the successful use of ICT for learning. In the empirical application that we have carried out, with data from a large-scale sample of 363,412 students enrolled in 13,215 schools in 48 countries, the results that we obtained strongly supported the evidence of a positive effect of the stock of human capital on ICT use for learning. When we considered the moderator-effect of the stock of human capital, we found that the relationship between ICT use and students' outcomes was greater the higher the stock of human capital of the countries was.

When we focused only on the variable ICT use at school, we found a negative relationship between students' outcomes and ICT use at school, in line with previous empirical research based on large-scale assessment data and a broad set of countries [7,29-31]. Petko et al. [31] stated that the relationship between students' outcomes and ICT might be influence more by students' positive experience in terms of quality using ICT than the quantity of its use. Zhang and Liu [30] suggested that this negative relationship could be explained by the overall unproductive use of ICT students, due to the mismatch between students' learning necessities and ICT pedagogical resources used in educational processes. Skryabin et al. [29] argued that this negative relationship might be influenced by specific 
uses of ICT and the narrow participation ICT programs have had in the curriculum. The study conducted for Falck et al. [7] was the only cross-country analysis that found a null effect of ICT use at school on students' outcomes. The authors stated that this null effect was explained by the opposite effects (positive or negative) depending on the ICT activity carried out. Other studies were based on single-country subsamples from large-scale assessments. They showed, overall, a negative link between students' outcomes and ICT use at school [2,23,25-28].

Nevertheless, we looked in a different direction to understand the relationship between ICT use at school and students' outcomes, hypothesizing that the countries' stock of human capital might be a positive externality in the relationship between students' outcomes and ICT use. We confirmed our hypothesis, according to previous arguments, that supported the role of the stock of human capital as a catalyst of new technologies $[15,16,36-38]$, which have the capacity to create and improve pedagogical and institutional educational environments [39-42] and to engage better teachers [45,46]. Regardless of the subject assessed and the human capital indicator considered, average years of schooling (BL) or average years of schooling weighted by the Mincerian rates of return to education (PWT), the moderator-effect of the stock of human capital turned the negative relationship between students' outcomes and ICT use at school into a positive one.

A key limitation of this study is that we have used a concept of human capital that considers only its educational dimension. The indicator of average years of schooling is the most commonly used in empirical studies; nevertheless, it does not account for other dimensions of the concept of human capital different from formal education, like health, experience, or on-the-job training [34]. It is also important to highlight that the measures of human capital we have incorporated in the analysis do not account for the quality of education, specifically measured by the results of international cognitive tests. We point out that, in the present study, it was not possible to account for these measures, as this was indeed the independent variable we explained in the model. Nevertheless, since one of the indicators we have used is the PWT stock of human capital and this is weighted by the rates of return to education, this measure can be considered to be accounting indirectly for the quality of education.

A future line of analysis may be based on the use of other indicators that offer new perspectives in the measurement of human capital. Coming research could consider employing multidimensional indicators that take into account different dimensions of the concept of human capital, beyond formal education. In this sense, as suggested by Gimenez [32], principal component analysis constitutes a good mathematical instrument to build multidimensional indicators with an international perspective. Another possible extension would consist in the use of human capital measurements based on the skills that individuals possess. Surveys such as the Programme for the International Assessment of Adult Competencies (PIAAC), carried out by the OECD, have pointed out the big differences that exist in labor force skills among developed countries. Therefore, the incorporation of data coming from PIAAC results a promising idea to extend the present analysis.

From a policy-making perspective, our results warn scholars and policy-makers about the role of the stock of human capital as a mediator to leverage the use of ICT for learning purposes. Along with the investment in ICT resources, a comprehensive policy to enhance countries' human capital should be boost, in order to take more advantage of technological change. This is particularly important for developing countries, in which the rate of ICT investment is higher [29], but their stock of human capital is lower than in their developed counterparts. In this sense, a practical implication of our research would consist of reinforcing the binomial between investment in ICT and human capital. As we have pointed out, they have substantial complementarities. We identify two clear examples of practical recommendations to leverage these complementarities. The first one would be the case of teacher training. The use of ICT in the classroom by teachers depends, to a large extent, on their training in instructional ICT skills. In this regard, $\operatorname{OECD}([63]$, p. 15) points out that its participation in professional development activities 
on ICT skills for teaching is crucial. What motivates the use of ICT by teachers is how well-prepared they feel after having received ICT-instructional training. For example, in the case of middle-income countries participating in PISA, it should be noted that up to $60 \%$ of Latin American teachers state that they need more professional development activities on ICT skills for teaching and, for $22 \%$, this need is substantial [63]. The second practical recommendation to reinforce the binomial between investment in ICT and human capital is to improve the digital literacy of workers. ICT capital stock per worker has been regarded a mechanism to take more advantage of technological change, which in turn is reflected in higher productivity [13]. ICT capital stock is highly correlated with abstract tasks, which tend to be associated with higher wages [64]. According to Bechichi et al. [65], who conducted research considering the OECD countries, there are significant gaps between the needs of skills and training among countries (overall, less developed countries required higher levels of training). The authors explained that these gaps condition the occupational transitions to more technological-based activities (abstract tasks) in order to avoid the risk of automation (the occupations at high risk of automation in these countries ranged from $1 \%$ to $6 \%$, depending on the country analyzed). The OECD Skills Strategy 2019 pointed out that life-long learning and making better use of digital technology as a learning device are two strategic imperatives to enhance education and training systems ([66], p. 25). Our findings also suggest that, at a time when a critical view of the role of ICT in education is beginning to prevail, policy-makers should bear in mind that the effect of ICT could be mediated by intermediate variables that offer a new perspective in the calculation of a more accurate contribution of ICT to learning.

Author Contributions: Conceptualization, G.G.; methodology, G.G. and L.V.-M.; software, L.V.-M.; formal analysis, G.G. and L.V.-M.; writing—original draft preparation, G.G. and L.V.-M.; writingreview and editing, G.G. and L.V.-M. All authors have read and agreed to the published version of the manuscript.

Funding: This research was funded by the Ministerio de Ciencia, Innovación y Universidades del Gobierno de España, project number EDU2016-76414-R.

Institutional Review Board Statement: It is our understanding that our research was conducted in accordance with ethics requirements of our universities and is exempt from research ethics committee oversight. The reason is that the BL, PWT and World Bank datasets contains only aggregated information at country-level and the PISA dataset is a source of public access in which subjects cannot be identified in anyway or exposed to risks, liabilities, or reputational damage.

Informed Consent Statement: Not applicable.

Data Availability Statement: The data used in this study is available for public use on the following websites: https:/ / www.oecd.org/pisa/data/2018database/ (accessed on 23 June 2021), http: / / www. barrolee.com/ (accessed on 23 June 2021), https://www.rug.nl/ggdc/productivity/pwt/?lang= en (accessed on 23 June 2021), and https:/ / data.worldbank.org/indicator/NY.GDP.PCAP.PP.CD (accessed on 9 May 2021). The code used to compile and analyze data was written in R. The code to replicate analysis and tables is available on the website: https://t.ly/PISA-Outcomes_Hc_ICTCLASS (accessed on 23 June 2021).

Conflicts of Interest: The authors declare no conflict of interest. The funders had no role in the design of the study; in the collection, analyses, or interpretation of data; in the writing of the manuscript, or in the decision to publish the results.

\section{References}

1. González-Betancor, S.M.; López-Puig, A.J.; Cardenal, M.E. Digital inequality at home. The school as compensatory agent. Comput. Educ. 2021, 168. [CrossRef]

2. Fernández-Gutiérrez, M.; Gimenez, G.; Calero, J. Is the use of ICT in education leading to higher student outcomes? Analysis from the Spanish Autonomous Communities. Comput. Educ. 2020, 157. [CrossRef]

3. Comi, S.L.; Argentin, G.; Gui, M.; Origo, F.; Pagani, L. Is it the way they use it? Teachers, ICT and student achievement. Econ. Educ. Rev. 2017, 56, 24-39. [CrossRef]

4. Spiezia, V. Educational Achievements? Student-level Evidence from PISA. OECD J. Econ. Stud. 2010, 2010, 1-22. [CrossRef] 
5. White, M.A.; McCallum, F. Crisis or catalyst? Examining COVID-19's implications for wellbeing and resilience education. In Wellbeing and Resilience Education; Routledge: Oxfordshire, UK, 2021; pp. 1-17.

6. Turban, E.; McLean, E.; Wetherbe, J. Information Technology for Management: Transforming Organizations in the Digital Economy, 4th ed.; Turban, E., McLean, E., Wetherbe, J., Eds.; Wiley: Hoboken, NJ, USA, 2004; Volume 2, ISBN 9780471229674.

7. Falck, O.; Mang, C.; Woessmann, L. Virtually no effect? Different uses of classroom computers and their effect on student achievement. Oxf. Bull. Econ. Stat. 2018, 80,1-38. [CrossRef]

8. Hu, X.; Gong, Y.; Lai, C.; Leung, F.K.S. The relationship between ICT and student literacy in mathematics, reading, and science across 44 countries: A multilevel analysis. Comput. Educ. 2018, 125, 1-13. [CrossRef]

9. Bulman, G.; Fairlie, R.W. Technology and education: Computers, software, and the internet. In Handbook of the Economics of Education; Hanushek, E.A., Machin, S., Woessmann, L., Eds.; Elsevier: Amsterdam, The Netherlands, 2016; Volume 5, pp. 239-280, ISBN 9781602442207.

10. Giambona, F.; Porcu, M. Student background determinants of reading achievement in Italy. A quantile regression analysis. Int. J. Educ. Dev. 2015, 44, 95-107. [CrossRef]

11. Benhabib, J.; Spiegel, M.M. Human capital and technology diffusion. In Handbook of Economic Growth; Elsevier: Amsterdam, The Netherlands, 2005; pp. 935-966.

12. Vandenbussche, J.; Aghion, P.; Meghir, C. Growth, distance to frontier and composition of human capital. J. Econ. Growth 2006, 11, 97-127. [CrossRef]

13. Lentini, V.; Gimenez, G. Depreciation of human capital: A sectoral analysis in OECD countries. Int. J. Manpow. 2019, 40, 1254-1272. [CrossRef]

14. Giménez, G.; López-Pueyo, C.; Sanaú, J. Human capital measurement in OECD countries and its relation to GDP growth and innovation. Rev. Econ. Mund. 2015, 2015.

15. Barcenilla, S.; Gimenez, G.; López-Pueyo, C. Differences in total factor productivity growth in the european union: The role of human capital by income level. Prague Econ. Pap. 2019, 28, 70-85. [CrossRef]

16. López-Pueyo, C.; Barcenilla, S.; Giménez, G. The two faces of human capital and their effect on technological progress. Panoeconomicus 2018, 65, 163-181. [CrossRef]

17. Rubach, C.; Lazarides, R. Computers in human behavior addressing 21st-century digital skills in schools-Development and validation of an instrument to measure teachers ' basic ICT competence beliefs. Comput. Human Behav. 2021, 118, 106636. [CrossRef]

18. Sangrà, A.; González-Sanmamed, M. The role of information and communication technologies in improving teaching and learning processes in primary and secondary schools. Res. Learn. Technol. 2016, 18, 207-220. [CrossRef]

19. Marco, J.; Winkler, R.; Matthias, S. Enhancing problem-solving skills with smart personal assistant technology. Comput. Educ. 2021, 165, 1-15. [CrossRef]

20. Allegra, M.; Chifari, A.; Ottaviano, S. ICT to train students towards creative thinking. Educ. Technol. Soc. 2001, 4, 48-53.

21. Shan Fu, J. ICT in Education: A critical literature review and its implications. Int. J. Educ. Dev. Using Inf. Commun. Technol. 2013, 9, 112-125.

22. Wheeler, S.; Waite, S.J.; Bromfield, C. Promoting creative thinking through the use of ICT. J. Comput. Assist. Learn. 2002, 18, 367-378. [CrossRef]

23. Gómez-Fernández, N.; Mediavilla, M. Exploring the relationship between information and communication technologies (ICT) and academic performance: A multilevel analysis for Spain. Socioecon. Plann. Sci. 2021. [CrossRef]

24. Hanushek, E.A.; Woessmann, L. The economics of international differences in educational achievement. In Handbook of the Economics of Education; Hanushek, E.A., Machin, S., Woessmann, L., Eds.; Elsevier: Amsterdam, The Netherlands, 2011; Volume 3, pp. 89-200, ISBN 9780444534293.

25. Cabras, S.; Tena Horrillo, J.d.D. A Bayesian non-parametric modeling to estimate student response to ICT investment. J. Appl. Stat. 2016, 43, 2627-2642. [CrossRef]

26. Alderete, M.V.; Di Meglio, G.; Formichella, M.M. Acceso a las TIC y rendimiento educativo: ¿una relación potenciada por su uso? Un análisis para España. Rev. Educ. 2017, 2017, 54-79. [CrossRef]

27. Erdogdu, F.; Erdogdu, E. The impact of access to ICT, student background and school/home environment on academic success of students in Turkey: An international comparative analysis. Comput. Educ. 2015, 82, 26-49. [CrossRef]

28. De Witte, K.; Rogge, N. Does ICT matter for effectiveness and efficiency in mathematics education? Comput. Educ. 2014, 75, 173-184. [CrossRef]

29. Skryabin, M.; Zhang, J.; Liu, L.; Zhang, D. How the ICT development level and usage influence student achievement in reading, mathematics, and science. Comput. Educ. 2015, 85, 49-58. [CrossRef]

30. Zhang, D.; Liu, L. How does ICT use influence students' achievements in math and science over time? Evidence from PISA 2000 to 2012. Eurasia J. Math. Sci. Technol. Educ. 2016, 12, 2431-2449. [CrossRef]

31. Petko, D.; Cantieni, A.; Prasse, D. Perceived quality of educational technology matters: A Secondary analysis of students ICT use, ICT-related attitudes, and PISA 2012 test scores. J. Educ. Comput. Res. 2017, 54, 1070-1091. [CrossRef]

32. Gimenez, G. The human capital endowment of Latin America and the Caribbean. CEPAL Rev. 2005, 2005, 97-116. [CrossRef]

33. Gimenez, G.; Simón, B. Comparación entre indicadores de capital humano en un modelo de crecimiento económico. Ekon. Rev. Vasca Econ. 2004, 57, 296-323. 
34. Winters, J.V. Human capital externalities and employment differences across metropolitan areas of the USA. J. Econ. Geogr. 2013, 13, 799-822. [CrossRef]

35. Gimenez, G. Introducción al Crecimiento Económico y Desarrollo; Ediciones Pirámide: Madrid, Spain, 2017 ; ISBN 8436836766.

36. Funke, M.; Strulik, H. On endogenous growth with physical capital, human capital and product variety. Eur. Econ. Rev. 2000, 44, 491-515. [CrossRef]

37. Labordeta, J.F.R.; Giménez, G. The effect of human capital on innovation: An analysis from the quantitative and qualitative perspectives of education. Intang. Cap. 2012, 8, 425-446. [CrossRef]

38. Gimenez, G. Investment in new technology: Modelling the decision process. Technovation 2006, 26, 345-350. [CrossRef]

39. Lochner, L.; Moretti, E. The effect of education on crime: Evidence from prison inmates, arrests, and self-reports. Am. Econ. Rev. 2004, 94, 155-189. [CrossRef]

40. Milligan, K.; Moretti, E.; Oreopoulos, P. Does education improve citizenship? Evidence from the United States and the United Kingdom. J. Public Econ. 2004, 88, 1667-1695. [CrossRef]

41. Reiter, C.; Özdemir, C.; Yildiz, D.; Goujon, A.; Guimaraes, R.; Lutz, W. The Demography of Skills-Adjusted Human Capital; IIASA Working Papers: Laxenburg, Austria, 2020.

42. Doms, M.; Lewis, E.; Robb, A. Local labor force education, new business characteristics, and firm performance. J. Urban Econ. 2010, 67, 61-77. [CrossRef]

43. Winters, J.V. Human capital, higher education institutions, and quality of life. Reg. Sci. Urban Econ. 2011, 41, 446-454. [CrossRef]

44. Shapiro, J.M. Smart cities: Quality of life, productivity, and the growth effects of human capital. Rev. Econ. Stat. 2006, 88, 324-335. [CrossRef]

45. Berlinski, S.; Ramos, A. Does Rewarding Pedagogical Excellence Keep Teachers in the Classroom? Evidence from a Voluntary Award Program; Inter-American Development Bank (IDB): Washington, DC, USA, 2018.

46. Correa, J.A.; Parro, F.; Reyes, L. Self-selection in the market of teachers. Appl. Econ. 2015, 47, 1331-1349. [CrossRef]

47. PISA. Available online: https://www.oecd.org/pisa/ (accessed on 17 May 2021).

48. Czernich, N.; Falck, O.; Kretschmer, T.; Woessmann, L. Broadband infrastructure and economic growth. Econ. J. 2011, 121, 505-532. [CrossRef]

49. Barro, R.J.; Lee, J.W. A new data set of educational attainment in the world, 1950-2010. J. Dev. Econ. 2013, 104, 184-198. [CrossRef]

50. PWT 10.0 । Penn World Table I Groningen Growth and Development Centre I University of Groningen. Available online: https:/ / www.rug.nl/ggdc/productivity/pwt/ (accessed on 15 May 2021).

51. Angrist, N.; Djankov, S.; Goldberg, P.K.; Patrinos, H.A. Measuring human capital using global learning data. Nature 2021, 592, 403-408. [CrossRef] [PubMed]

52. Psacharopoulos, G. Returns to investment in education: A global update. World Dev. 1994, 22, 1325-1343. [CrossRef]

53. Gimenez, G.; Barrado, B. Exposure to crime and academic achievement: A case study for Costa Rica using PISA data. Stud. Educ. Eval. 2020, 65, 100867. [CrossRef]

54. Castro Aristizabal, G.; Giménez, G.; Pérez Ximénez-De-Embún, D. Educational inequalities in latin america, PISA 2012: Causes of differences in school performance between public and private schools. Rev. Educ. 2017, 2017. [CrossRef]

55. Castro Aristizabal, G.; Giménez, G.; Pérez Ximénez-de-Embún, D. Estimation of factors conditioning the acquisition of academic skills in Latin America in the presence of endogeneity. CEPAL Rev. 2018, 2018, 33-55. [CrossRef]

56. Fuchs, T.; Woessmann, L. What accounts for international differences in student performance? A re-examination using PISA data. Empir. Econ. 2007, 32, 433-464. [CrossRef]

57. Ammermueller, A. PISA: What makes the difference? Explaining the gap in test scores between Finland and Germany. Empir. Econ. 2007, 33, 263-287. [CrossRef]

58. Zhang, L.; Khan, G.; Tahirsylaj, A. Student performance, school differentiation, and world cultures: Evidence from PISA 2009. Int. J. Educ. Dev. 2015, 42, 43-53. [CrossRef]

59. The Economics of Education; Bradley, S.; Green, C. (Eds.) Elsevier: New York, NY, USA, 2020; ISBN 9780128153918.

60. Hanushek, E.A.; Welch, F. The Handbook of the Economics of Education, 1st ed.; Hanushek, E.A., Welch, F., Eds.; Elsevier: Amsterdam, The Netherlands, 2006; Volume 1.

61. Hanushek, E.A.; Woessmann, L.; Machin, S. Handbook of the Economics of Education, 1st ed.; Hanushek, E.A., Woessmann, L., Machin, S., Eds.; Elsevier: Amsterdam, The Netherlands, 2011; Volume 4, ISBN 9780444534446.

62. Wooldridge, J.M. Introductory Econometrics, 4th ed.; South-Western CENGAGE Learning: Mason, OH, USA, 2009; ISBN 9783319659169.

63. OECD. Aprovechar al Máximo la Tecnología para el Aprendizaje y la Formación en América Latina; OECD Publishing: Paris, France, 2020.

64. La Rica, S.D.; Gortazar, L.; Lewandowski, P. Job Tasks and wages in developed countries: Evidence from PIAAC. Labour Econ. 2020, 65, 1-36. [CrossRef]

65. Bechichi, N.; Jamet, S.; Kenedi, G.; Grundke, R.; Squicciarini, M. Occupational mobility, skills and training needs. OECD Policy Pap. 2019, 67. [CrossRef]

66. OECD. Going digital integrated policy framework. OECD Digit. Econ. Pap. 2020, 292, 67. 